\title{
Invasive Macroinvertebrate Species Monitored in the Turkish Coast between 2014 and 2015
}

\section{4 - 2015 Yılları Arasında Türkiye Kıyılarında İzlenen İstilacı Makroomurgasız Türler}

\author{
Serdar KOYUN ${ }^{1}$, Tahir ÖZCAN ${ }^{2}$ \\ ${ }^{1}$ Ministry of Forestry and Water Affairs, General Directorate of Water Management, 06150, \\ Yenimahalle-Ankara \\ serdarkoyun@ormansu.gov.tr \\ ${ }^{2} \dot{I}$ skenderun Technical University, Marine Sciences and Technology Faculty, 31200, \\ Iskenderun-Hatay \\ tahir.ozcan@iste.edu.tr \\ Received Date: 08.01.2018, Accepted Date: 08.05.2018
}

\begin{abstract}
Invasive species has been accepted as one of the major threats to aquatic ecosystems. The biological invasion has resulted in significant ecological degradations including alteration of the structure of populations and changes in ecosystems processes and services. There are a variety of reasons why invaders have introduced to new aquatic areas, such as dense marine traffic, anthropogenic modifications, extreme human use of water bodies. To display the status of aquatic ecosystem in terms of the invasive species, benthic invertebrate communities are a very good indicator. A study was carried out in Turkish coasts during the "Project on Establishment of the Water Quality Ecological Assessment System Specific for Turkey" for biomonitoring studies between 2014 and 2015. In the scope of the project, 4 invasive species Polydora cornuta Bosc, 1802; Prionospio saccifera Mackie \& Hartley, 1990; Cerithium scabridum Philippi, 1848 and Rapana venosa (Valenciennes, 1846) were identified. Some geographical distribution data of these species are briefly examined.

Keywords: Invasive species, benthic macroinvertebrate, biomonitoring, Mediterranean and Black Sea, Turkey

\section{$\ddot{\mathbf{O} z}$}

İstilacı türler, su ekosistemleri için en büyük tehditlerden biri olarak kabul edilir. Biyolojik istila, popülasyon yapısının değişmesi ve ekosistem süreçleri ve hizmetlerindeki aksaklıklar dahil olmak üzere önemli ekolojik bozulmalara neden olur. Deniz taşımacılığı, antropojenik modifikasyonlar, su kütlelerinin aşırı kullanımı gibi faktörler, istilacı türlerin yeni sucul bölgelere giriş yapmasındaki nedenlerdir. İstilacı türler açısından sucul ekosistemlerin durumlarını göstermek için bentik omurgasız toplulukları çok iyi indikatördürler. 2014 ve 2015 yılları arasında "Türkiye'ye Özgü Su Kalitesi Ekolojik Değerlendirme Sisteminin Kurulması Projesi" kapsamında biyolojik izleme çalışmaları için Türkiye kıyılarında bir çalışma yürütülmüştür. Proje kapsamında 4 istilacı tür tespit edildi; Polydora cornuta Bosc, 1802; Prionospio saccifera Mackie \& Hartley, 1990; Cerithium scabridum Philippi,
\end{abstract}


1848 ve Rapana venosa (Valenciennes,1846). Bu türlerin bazı coğrafik dağılım verileri kısaca incelenmiştir.

Anahtar kelimeler: İstilacı türler, makroomurgasılar, biyolojik izleme, Akdeniz ve Karadeniz, Türkiye.

\section{Introduction}

Globally, invasive species has been regarded as one of the greatest threats to marine biodiversity (Simberloff et al., 2013). The rate of biological invasion has risen over the last century, is generating big concern due to the ecological and financial losses of invasion (Mack et al., 2000; Katsanevakis et al., 2013; Simberloff, 2014), and according to Pysek \& Richardson (2010), this rate will possibly remain in the future. It is estimated that on indigenous populations invasive species have the most important pressures including that predominate over their assemblages and/or introduce different features to ecosystems (Shea \& Chesson, 2002; Hall et al., 2006). It is responsible for alteration in the structure and composition of populations (e.g. diversity, spatial distribution, density) (Fritts \& Rodda, 1998; O'Dowd et al., 2003) and changes in the ecosystem function (e.g. nitrogen cycling, light penetration) (Grosholz, 2002; Byrnes et al., 2007; Costello et al., 2010) which are important environmental damages.

Natural and anthropogenic global environmental changes influence the geographical and biological implications of invasions (Lapointe et al., 2012). Utilisation of rivers, lakes, and the coastal waters excessively by the human is usually joined by intentional or unintentional invader introductions. Invasive species dispersals in aquatic ecosystems have been occurring by human activities (Lockwood et al., 2013) such as aquaculture, canal building, recreational events, shipping (i.e. ballast water discharge), tourism and sports fisheries in the last few decades (Cohen \& Carlton, 1998; Zenetos et al., 2012; Nunes et al., 2014). The structure of many aquatic ecosystems are being altered by anthropogenic modifications (Friberg, 2014) and ecological assessment for all water bodies is carried out through biomonitoring studies that have turned into a basic method for assessing and monitoring such impacts (Olenin et al., 2010; Buss, 2015).

According to the Marine Strategy Framework Directive (MSFD), the biological invasion is regarded highly in the biodiversity and marine ecosystem policies of EU (Directive, E.C., 2008; EU Commission, 2011). In the assessment of the environmental quality of marine waters, the richness and functional attributes of invasive species will be employed as criteria (European Commission, 2010), since that new alien species are entered European seas every year (Evagelopoulos et al., 
2015; Katsanevakis et al., 2013). Determination of the ecological status of freshwaters and coastal waters are being done by using many biological quality elements including benthic macroinvertebrates, phytoplankton, macro algae, fish (Hellawell, 1986; Rosenberg \& Resh, 1993; Carter et al., 2006; Boix \& Batzer, 2016). Among these biological assemblages, benthic macroinvertebrates are the most common bio-indicator, are designated as one of the biological quality elements used in the implementation of the EU Water Framework Directive (WFD; EC, 2000). Benthic macroinvertebrate species in aquatic environment has strong trophic relations that could be intensely distressed by the introduction or the loss of species, therefore the development of a bio-monitoring instruments have been empowered via presence of indicative benthic invertebrate taxa and communities (Carpenter et al., 1985; Strong, 1992; Pace et al., 1999; Bonada et al., 2006). However, there is a lack of consensus on containing or given score values with regard to invasive species and biotic indices (Gabriel et al., 2005; Arndt et al., 2009; MacNeil et al., 2013).

The coasts of Turkey have different hydrodynamic systems and marine traffic characteristics. The Dardanel and Bosphorus Straits constitute the dense shipping activities in Turkey and invasive species have entered locations through these commercial ports being hotspots for invasive species. Also, intense populating of Lessepsian migrants has resulted from the Suez Canal along the Levantine coast of Turkey. (Çinar et al., 2006). In the country, the impacts of invasive species on ecosystems and their roles in the aquatic environment is becoming a subject of study (Çinar et al., 2016). This paper reviews the invasive species reported from the Turkish coasts during a project funded by Ministry of Forestry and Water Affairs, General Directorate of Water Management (Project of Establishing Water Quality Ecological Evaluation System Specialized to Turkey, Project No: 2011K050400) was conducted for bio-monitoring studies between 2014 and 2015.

\section{Material and Methods}

The benthic macroinvertebrate species were monitored at 46 stations along Turkish coasts, but invasive species were only recorded at 5 stations located in the Mediterranean (2), Levantine coasts (1) of Turkey and East Black Sea (2) (Fig. 1). 


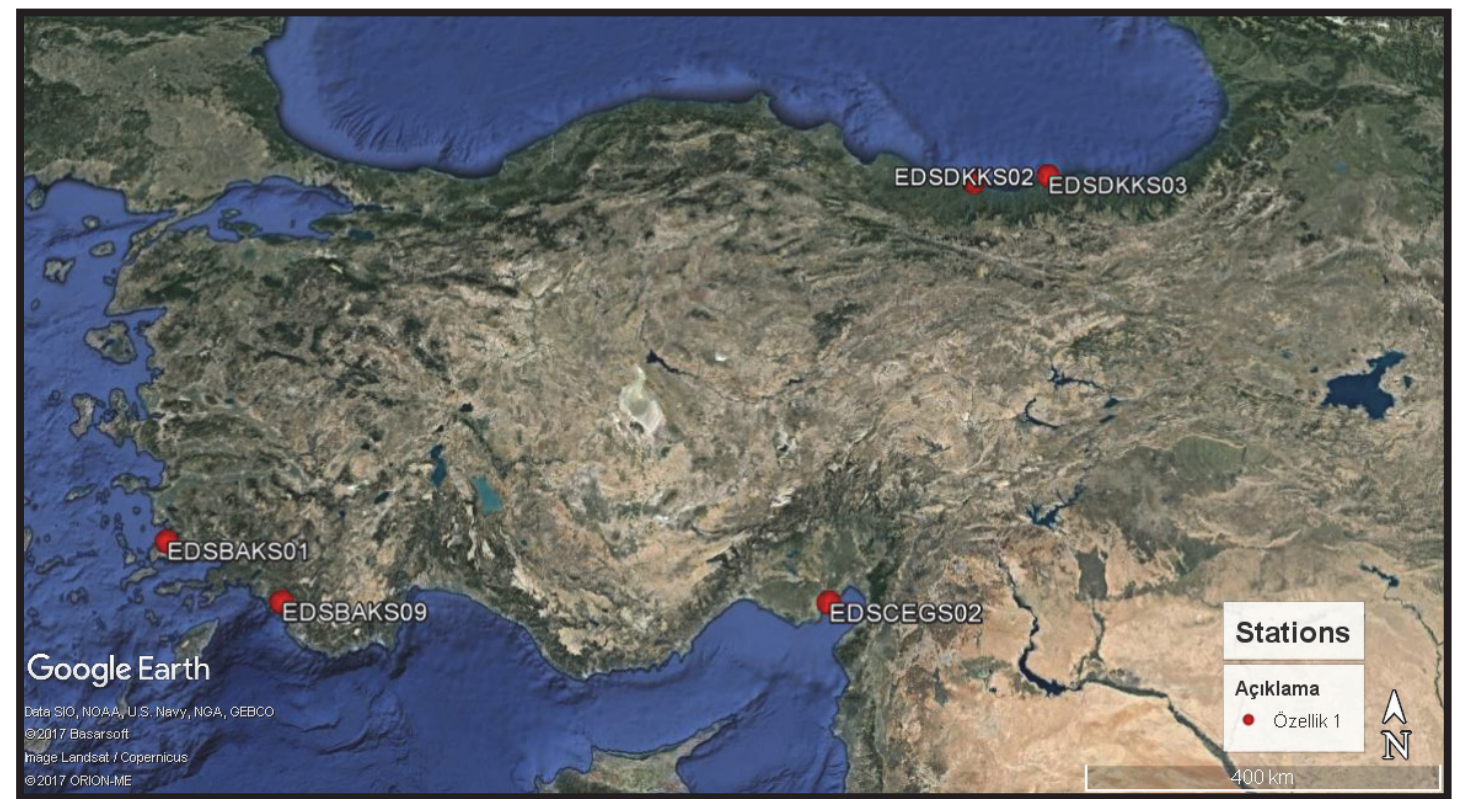

Figure 1: The location of 5 sampling stations where invasive species were found.

The coordinates of five stations are also represented in Table 1.

Table 1

The Coordinates of Five Stations

\begin{tabular}{lll}
\hline Station / Coordinates & Longitude (X) & Latitude (Y) \\
\hline EDSBAKS01 & 55,3774 & 41,24024 \\
EDSBAKS09 & 68,8656 & 40,58866 \\
EDSDKKS02 & 41,0274 & 45,38094 \\
EDSDKKS03 & 48,6718 & 45,40383 \\
EDSCEGS02 & 37,154418 & 37,57956 \\
\hline
\end{tabular}

Sampling process was conducted in summer, autumn, spring and summer seasons, respectively. Due to harsh winter conditions, the material was not sampled in winter period. The biodiversity and benthic community structures of the area were documented by performing qualitative and quantitative samplings at stations. At all monitoring stations, the sampling of soft substrate macrofauna was carried out between 2014 and 2015 with Van Veen Grab $\left(0.1 \mathrm{~m}^{2}\right.$ sampling area) as three replicates. Soft-bottom samples were filtered through a wash bucket with $0.5 \mathrm{~mm}$ mesh. The retained material was placed in separate boxes containing a $4 \%$ 
formaldehyde solution. In the laboratory, the samples were rinsed in fresh water and identified to the species level under a stereomicroscope and protected in $70 \%$ ethanol.

The temperature and salinity values were measured in situ. All water quality parameters results of stations are presented in Table 2.

Table 2

Monthly Records of Mean Water Quality Parameters at the Five Sites

\begin{tabular}{|c|c|c|c|c|c|c|c|c|}
\hline Test site & Season & $\begin{array}{l}\text { Temp. } \\
{\left[{ }^{\circ} \mathrm{C}\right]}\end{array}$ & $\begin{array}{l}\text { Sal. } \\
{[\mu \mathrm{g} / \mathrm{L}]}\end{array}$ & pH & $\begin{array}{l}\text { DO } \\
{[\mathrm{mg} / \mathrm{L}]}\end{array}$ & $\begin{array}{l}\text { TSS } \\
\mathrm{mg} / \mathrm{L}\end{array}$ & 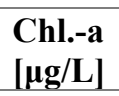 & $\begin{array}{l}\mathrm{L.A} \\
{[\mu \mathrm{g} / \mathrm{L}]}\end{array}$ \\
\hline \multicolumn{9}{|l|}{ EDSBAKS01 } \\
\hline & 1 & 25,55 & 49,90 & 8,19 & 8,08 & 68,80 & 3,10 & 1,20 \\
\hline & 2 & 19,00 & 28,53 & 7,99 & 7,08 & 61,20 & 3,10 & 4,00 \\
\hline & 3 & 19,65 & 25,99 & 7,85 & 7,24 & 14,40 & 0,10 & 3,70 \\
\hline & 4 & 29,30 & 33,30 & 8,25 & 8,87 & 17,60 & 0,10 & 2,50 \\
\hline \multicolumn{9}{|l|}{ EDSBAKS09 } \\
\hline & 1 & 30,10 & 50,10 & 8,30 & 7,86 & 42,80 & 3,10 & 0,80 \\
\hline & 2 & 21,25 & 36,75 & 8,35 & 9,51 & 33,20 & 3,10 & 3,00 \\
\hline & 3 & 21,55 & 35,70 & 7,96 & 9,61 & 46,60 & 0,10 & 1,80 \\
\hline & 4 & 28,45 & 40,75 & 8,32 & 8,61 & 46,20 & 0,10 & 4,00 \\
\hline \multicolumn{9}{|l|}{ EDSDKKS02 } \\
\hline & 2 & - & - & - & - & - & - & - \\
\hline & 3 & 22,05 & 12,31 & 8,32 & 9,31 & 10,40 & 0,10 & 6,00 \\
\hline \multirow{2}{*}{\multicolumn{9}{|c|}{ EDSDKKS03 }} \\
\hline & & & & & & & & \\
\hline & 2 & - & - & - & - & - & - & - \\
\hline & 3 & 22,15 & 10,72 & 8,44 & 9,36 & 3,20 & 0,10 & 0,50 \\
\hline & 4 & 27,00 & 17,59 & 8,59 & 8,06 & 28,40 & 0,10 & 6,00 \\
\hline \multicolumn{9}{|l|}{ EDSCEGS02 } \\
\hline & 1 & 29,60 & 40,44 & 8,26 & 7,41 & 54,20 & 3,10 & - \\
\hline & 2 & 22,55 & 41,15 & 8,40 & 8,91 & 9,40 & 3,10 & 0,90 \\
\hline & 3 & 26,90 & 41,15 & 7,89 & 8,70 & 25,60 & 0,10 & 1,50 \\
\hline & 4 & 28,25 & 41,45 & 8,32 & 8,26 & 55,40 & 0,10 & 1,00 \\
\hline
\end{tabular}

Note. $(1=$ summer 2014, $2=$ autumn 2014, 3= Spring 2015, 4= Summer 2015)

Temp=temperature, $S a l=$ salinity, $D O=$ dissolved oxygen, $T S S=$ total suspended solid, $C h l .-a=$ chlorophyll-a, $L . A=$ light availability 


\section{Results and Discussion}

During the project, 7 alien species, 4 invasive species presented in the following section from the Turkish coasts were identified.

\section{Polydora cornuta Bosc, 1802 (Spionidae: Polychaeta)}

Soft and hard bottom samples collected to examine from the station EDSBAKKS01 in summer, 2015 (Fig. 3) showed that invasive species, identified as Polydora cornuta Bosc, 1802 (Fig. 2), in the western Mediterranean coast of Turkey.

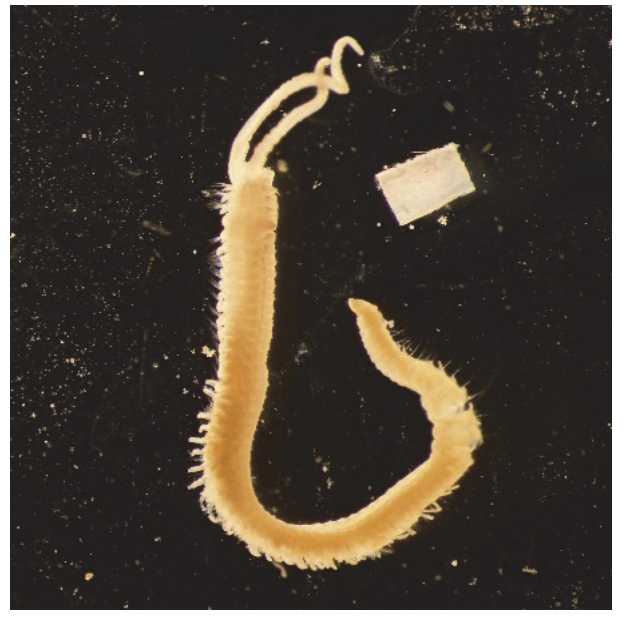

Figure 2: Polydora cornuta

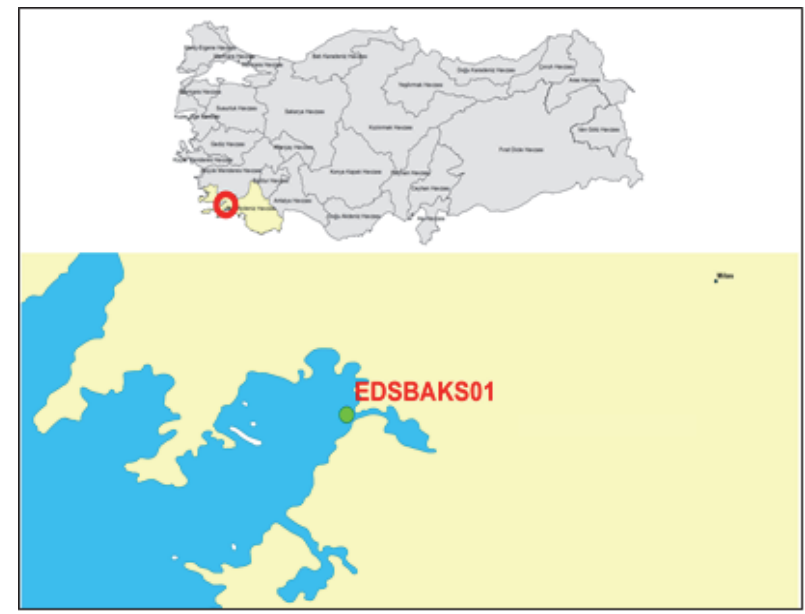

Figure 3: EDSBAKS01 station

This species has been reported from different regions of the world oceans including the western Mediterranean Sea, is broadly dispersed from the Atlantic to the Pacific Ocean (Radashevsky \& Hsieh, 2000). In the Mediterranean Sea, the spionid $P$. cornuta is considered to be one of the worst invasive alien species on benthic substrates (Streftaris \& Zenetos, 2006). The first record in the Mediterranean Sea was reported by Tena et al., (1991) in organically enriched environments in the Spanish coast (Valencia Harbour). In Turkey, Çınar et al., (2005) encountered this species from the Alsancak Harbour in İzmir Bay, the Aegean Sea. The presence of $P$. cornuta in the Sea of Marmara and İzmir Bay (Aegean Sea) (Dağlı \& Ergen, 2008), the Bosphorus Strait (Karhan et al., 2008) and the Greek waters (Simboura et al., 2008) provided that its distributional range increased within the Mediterranean and Black Sea. Although the routes of these species continue uncertain in the 
Mediterranean (Radashevsky \& Selifonova, 2013), shipping and aquaculture have been widely considered as pathways for the introduction of $P$. cornuta into the Mediterranean Sea, as the specimens were found in and around the busiest commercial harbours and mussel farm areas (Çınar et al., 2005, Simboura et al., 2008). In all these cases, $P$. cornuta was identified as an opportunistic species and also it has been commonly sampled in organically polluted sediments (Pearson \& Rosenberg, 1978).

\section{Prionospio saccifera Mackie \& Hartley, 1990 (Spionidae: Polychaeta)}

Specimens of Prionospio saccifera were collected in the station EDSBAKS09 in spring, 2015 (Fig. 4) in the Mediterranean Sea. It was firstly recorded from Hong Kong at 11-21 m depth and the Red Sea at 43-49 m depth by Mackie \& Hartley (1990). Blake (1996) considered P. saccifera as very common in the western Pacific and the Indian Ocean. This species could have been introduced to the Mediterranean Sea from the Red Sea through the Suez Canal (Lessepsian migrants) (Dağlı \& Çınar, 2010). The occurrence of this species in the Mediterranean Sea was first mentioned by Çınar and Ergen (1999). Çinar \& Ergen (1999) mentioned that reporting this species in the western Mediterranean Sea extends its worldwide distribution, after Hong Kong and the Gulf of Suez (Red Sea), a phenomenon of Lessepsian migration may be hypothesized

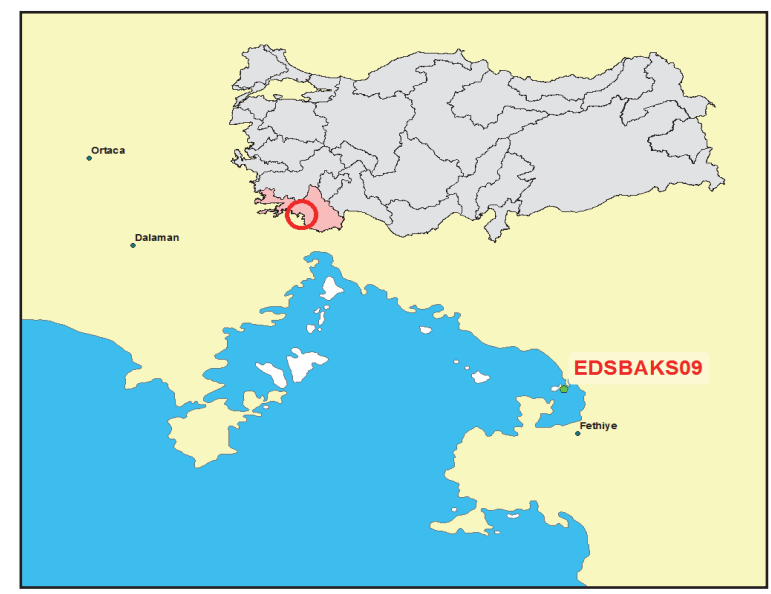

Figure 4: EDSBAKS09 station

\section{Cerithium scabridum Philippi, 1848 (Cerithiidae: Gastropoda)}

The presence of an established population of Cerithium scabridum (Fig. 5) in the Mediterranean Sea was reported by Zenetos et al. (2009). In this study, these 
species were sampled from the EDSCEGS02 station in spring, 2015 (Fig. 6) in the Levantine coast of Turkey. The presence of $C$. scabridum in the western Mediterranean is likely due to shipping from the eastern Mediterranean (Garilli \& Caruso, 2004). On the contrary, other dispersion mechanism of this species can be with natural way via the Suez Canal along the Levantine Sea, it is called as Lessepsian migration (Zenetos et al., 2009). As the pattern is known for other IndoPacific species, C. scabridum from the Suez Canal recorded in Egypt, Israel, Lebanon, Syria, the southern coast of Turkey and Cyprus (Houbrick, 1992). It is supposed that the distribution pattern of $C$. scabridum has been explained with a double dispersal mechanism.

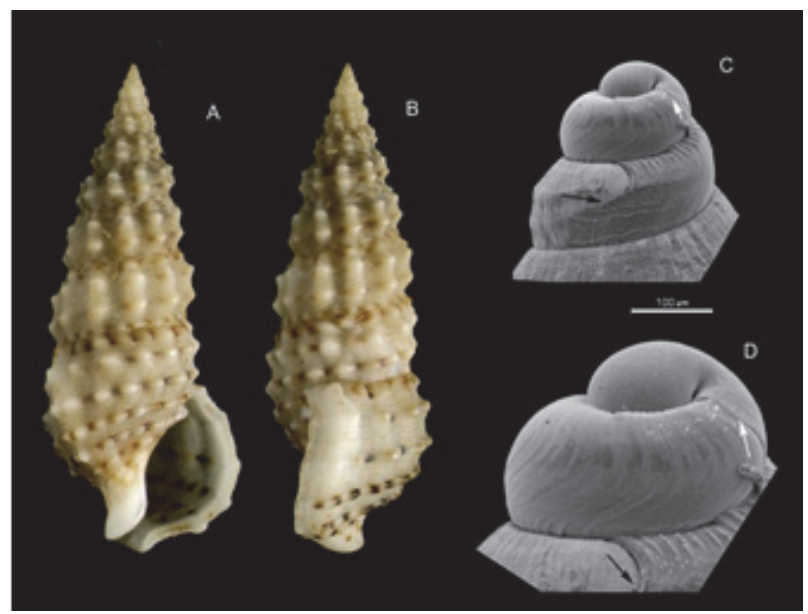

Figure 5: Cerithium scabridum adopted from WoRMS image, n d(a).

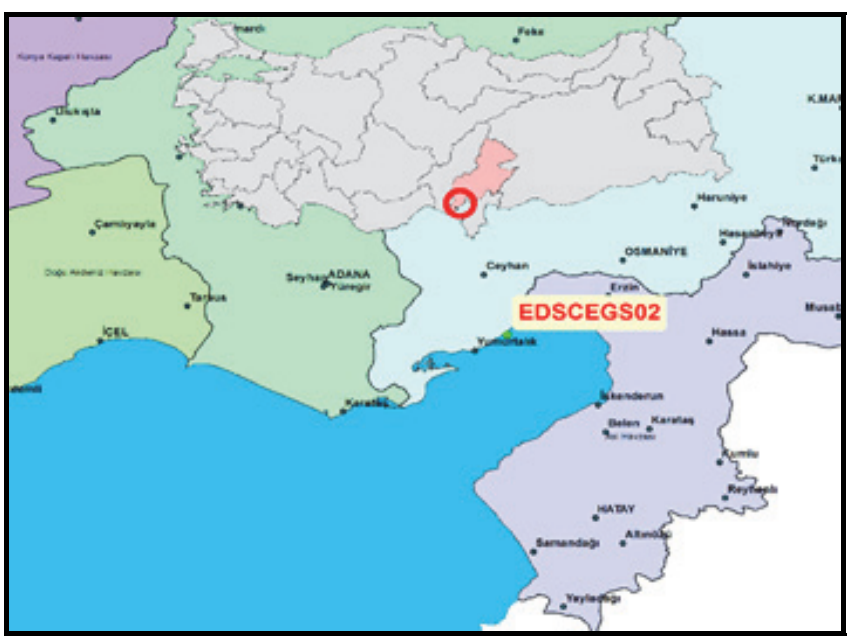

Figure 6: EDSCES02 station 


\section{Rapana venosa (Valenciennes, 1846) (Muricidae: Gastropoda)}

Rapana venosa species (Fig. 7) were collected from two stations (EDSDKKS02, Spring 2015 and EDSDKKS03, Summer 2014) (Fig. 8 \& Fig. 9) in the eastern region of the Turkish coast of the Black Sea. Rapana venosa is a large predator originating from temperate Asian waters, such as the Sea of Japan, the Yellow Sea (Chung et al., 1993), the Bohai Gulf, and the east China Sea. It was first introduced to the Black Sea in 1947, has since spread into the Aegean Sea (Koutsoubas \& Voultsiadou-Koukoura, 1991), the Adriatic Sea (Bombace et al., 1994). In the Black Sea, due to lack of major predators, $R$. venosa has become very abundant (Saglam \& Duzgunes, 2007). In the late 1990s, the larvae of this species carried by ballast water from the Black Sea or from the Levantine Sea into the Chesapeake Bay (Atlantic basin). This successful invasion is supported by various factors such as appropriate sandy bottom areas and an abundant supply of bivalve prey (Saglam \& Duzgunes, 2007).

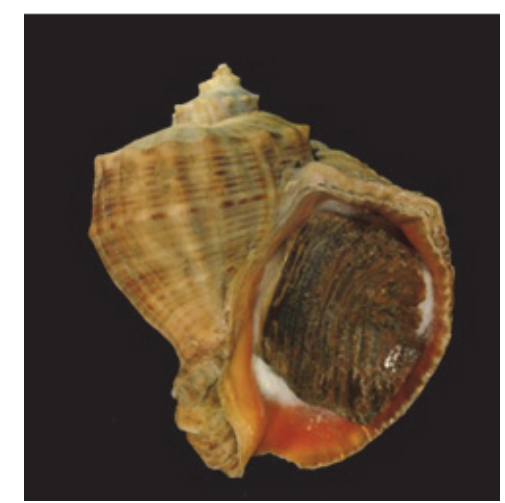

Figure 7: Rapana venosa adopted from WoRMS image, $\mathrm{n} \mathrm{d(b).}$

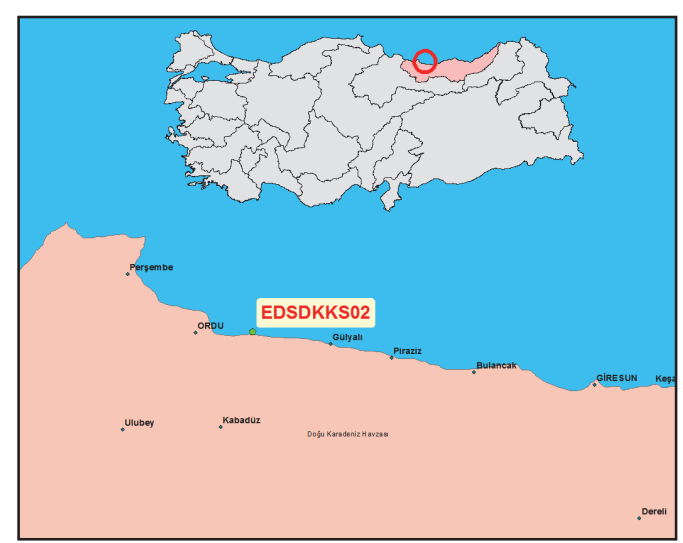

Figure 8: EDSDKKS02 station

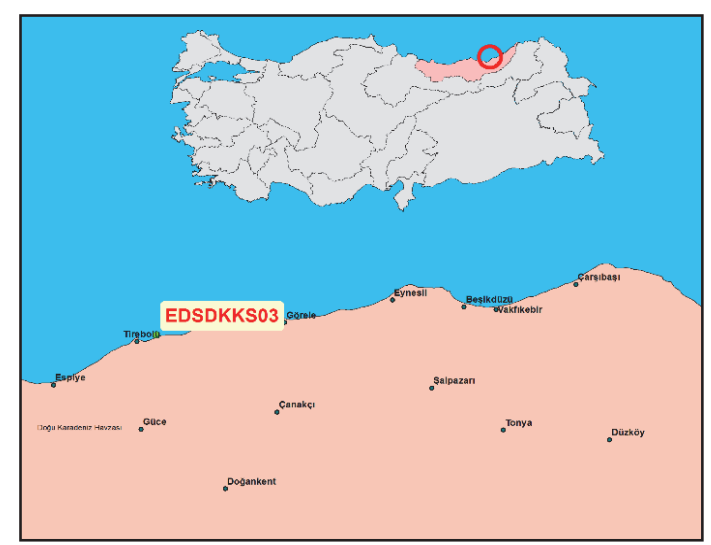

Figure 9: EDSDKKS03 station 


\section{Conclusion}

The biological invasion has resulted in significant ecological deteriorations including alteration of the population dynamics, biodiversity and ecosystem services. However, recognizing these alterations is not an easy task except where large, wellknown species are of concern. There are especially two ways how invaders have introduced to new aquatic areas, natural ways such as carried by currents (e.g. larvae of invertebrates), attached to a piece of driftwood and human-based ways such as maritime transport, ballast waters and aquaculture. In Turkey, the marine invasive ecology has come into focus and spatial range of invasive species has expanded for coastal habitats in the last years. Having commercial ports take place in Turkey costal and opening Suez Canal in the Levantine coast of Turkey make a contribution to this situation. In this project, 4 invasive species recorded from different coasts indicate that invasive species has become a threat to the Turkey coasts. Although the impacts of invasive species on ecosystems and their roles in the aquatic environment have become subjects of study in Turkey, these studies are still mainly based on morphological examination and comparison of fixed specimens. The biogeographic origin of a species and its morphological variability can be the subject of future projects in biological monitoring studies in Turkey.

\section{Acknowledgement}

This study was implemented by the Ministry of Forestry and Water Affairs, General Directorate of Water Management (Project of Establishing Water Quality Ecological Evaluation System Specialized to Turkey, Project No: 2011K050400, between March 2014 and September 2016). I gratefully thank my colleagues in the Department of Monitoring and Water Information System of the Ministry. 


\section{References}

Arndt, E., Fiedler, S., \& Böhme, D. (2009). Effects of invasive benthic macroinvertebrates on assessment methods of the EU Water Frame Work Directive. Hydrobiologia, 635(1), 309.

Blake, J. A. (1996). Family Spionidae Grube, 1850. Taxonomic atlas of the benthic fauna of the Santa Maria Basin and Western Santa Barbara Channel, 6, 81-223.

Boix, D., \& Batzer, D. (2016). Invertebrate assemblages and their ecological controls across the world's freshwater wetlands. Invertebrates in Freshwater Wetlands, Springer International Publishing, Basel, 601-639.

Bombace, G., Fabi, G., Fiorentini, L., \& Speranza, S. (1994). Analysis of the efficacy of artificial reefs located in five different areas of the Adriatic Sea. Bulletin of Marine Science, 55(2-3), 559-580.

Bonada, N., Prat, N., Resh, V. H., \& Statzner, B. (2006). Developments in aquatic insect biomonitoring: a comparative analysis of recent approaches. Annual Review of Entomology, 51, 495-523.

Buss, D.F., Carlisle, D.M., Chon, T.S., Culp, J., Harding, J.S., Keizer-Vlek, H.E., ... Hughes, R.M. (2015). Stream biomonitoring using macroinvertebrates around the globe: a comparison of large-scale programs. Environmental Monitoring and Assessment, 187(1), 4132.

Byrnes, J. E., Reynolds, P. L., \& Stachowicz, J. J. (2007). Invasions and extinctions reshape coastal marine food webs. PLOS/ONE, 2(3), e295. Retrieved from http://journals.plos.org/plosone/ article/authors? $\mathrm{id}=10.1371 /$ journal.pone.0000295

Carpenter, S. R., Kitchell, J. F., \& Hodgson, J. R. (1985). Cascading trophic interactions and lake productivity. BioScience, 35(10), 634-639.

Carter, J.L., Resh, V.H., Rosenberg, D.M. \& Reynoldson, T.B. (2006). Biomonitoring in North American Rivers: a comparison of methods used for benthic macroinvertebrates in Canada and United States. in: Ziglio, G., Flaim, G., Sillgardi, M. (Eds.) Biological Monitoring of Rivers. John Wiley. Retrieved from: https://onlinelibrary.wiley.com/doi/abs/10.1002/rra.1116

Çınar, M. E., \& Ergen, Z. (1999). Occurrence of Prionospio saccifera (Spionidae: Polychaeta) in the Mediterranean Sea. Cahiers de Biologie Marine, 40, 105-112.

Çınar, M. E., Bilecenoglu, M., Öztürk, B., \& Can, A. (2006). New records of alien species on the Levantine coast of Turkey. Aquatic Invasions, 1(2), 84-90.

Çınar, M. E., Bilecenoglu, M., Ozturk, B., Katagan, T., \& Aysel, V. (2016). Alien species on the coasts of Turkey. Mediterranean Marine Science, 6(2), 119-146. 
Çınar, M. E., Ergen, Z., Dagli, E., \& Petersen, M. E. (2005). Alien species of spionid polychaetes (Streblospio gynobranchiata and Polydora cornuta) in Izmir Bay, Eastern Mediterranean. Journal of the Marine Biological Association of the United Kingdom, 85(4), 821-827.

Cohen, A. N., \& Carlton, J. T. (1998). Accelerating invasion rate in a highly invaded estuary. Science, 279 (5350), 555-558.

Costello, M. J., Coll, M., Danovaro, R., Halpin, P., Ojaveer, H., \& Miloslavich, P. (2010). A census of marine biodiversity knowledge, resources, and future challenges. PloS one, 5(8), e12110.

Dağl1, E., \& Çınar, M. E. (2010). Presence of the Australian spionid species, Prionospio paucipinnulata (Polychaeta: Spionidae), in the Mediterranean Sea. Cahiers de Biologie Marine, 51(3), 311.

Dağlı, E., \& Ergen, Z. (2008). First record of Polydora cornuta Bosc, 1802 (Polychaeta: Spionidae) from the Sea of Marmara, Turkey basin. Aquatic Invasions, 3, 231-233. doi: 10.3391/ai.2008.3.2.13

Directive, E.C. (2008). 56/EC of the European Parliament and of the Council of 17 June 2008 establishing a framework for community action in the field of marine environmental policy (Marine Strategy Framework Directive). Official Journal of the European Union, 164, 19-40.

European Commission. (2010). Commission Decision of 1 September 2010 on criteria and methodological standards on good environmental status of marine waters (notified under document C (2010) 5956)(2010/477/EU). Official Journal of the European Union L 232/14.

EU Commission. (2011). Our life insurance, our natural capital: an EU biodiversity strategy to 2020. COM (2011), 244.

EC. (2000). Directive 2000/60/EC of the European Parliament and of the Council of 23 October 2000 establishing a framework for the community action in the field of water policy. Official Journal of the European Communities, 43, 1-73.

Eu-Yung, C. (1993). Reproductive ecology of the purple shell, Rapana venosa (Gastropoda: Muricidae), with special reference to the reproductive cycle, depositions of egg capsules and hatchings of larvae. The Korean Journal of Malacology, 9(2), 1-15.

Evagelopoulos, A., Poursanidis, D., Papazisi, E., Gerovasileiou, V., Katsiaras, N., \& Koutsoubas, D. (2015). Records of alien marine species of Indo-Pacific origin at Sigri Bay (Lesvos Island, north-eastern Aegean Sea). Marine Biodiversity Records, 8(e35), 1-10. 
Friberg, N. (2014). Impacts and indicators of change in lotic ecosystems. Wiley Interdisciplinary Reviews: Water, 1(6), 513-531.

Fritts, T. H., \& Rodda, G. H. (1998). The role of introduced species in the degradation of island ecosystems: A case history of guam 1. Annual review of Ecology and Systematics, 29(1), 113-140.

Gabriels, W., Goethals, P. L. M., \& De Pauw, N. (2005). Implications of taxonomic modifications and alien species on biological waterquality assessment as exemplified by the Belgian Biotic Index method. Hydrobiologia, 542(1), 137-150.

Garilli, V., \& Caruso, T. (2004). Records of Cerithium scabridum Philippi, 1848 (Caenogastropoda, Cerithiidae) from Northwestern Sicily. Bollettino Malacologico, 39(9/12), 157-160.

Grosholz, E. (2002). Ecological and evolutionary consequences of coastal invasions. Trends in Ecology \& Evolution, 17(1), 22-27.

Hall, R. O., Dybdahl, M. F., \& VanderLoop, M. C. (2006). Extremely high secondary production of introduced snails in rivers. Ecological Applications, 16(3), 1121-1131.

Harding, J.M., \& Mann, R. (1999). Observations on the biology of the veined rapa whelk, Rapana venosa (Valenciennes, 1846) in the Chesapeake Bay. Journal of Shellfish Research, 18(1), 918.

Hellawell, J.M. (Ed.). (2012). Biological indicators of freshwater pollution and environmental management. London\&Newyork: Springer Science \& Business Media.

Houbrick, R.S. (1992). Monograph of the genus Cerithium Bruguière in the Indo-Pacific (Cerithiidae: Prosobranchia), Smithsonian Contributions to Zoology 510: 1-211.

Karhan, S.Ü., Kalkan, E., Simboura, N., Mutlu, E., \& Bekbölet, M. (2008). On the occurrence and established populations of the alien polychaete Polydora cornuta Bosc, 1802 (Polychaeta: Spionidae) in the Sea of Marmara and the Bosphorus Strait (Turkey). Mediterranean Marine Science, 9(1), 5-19.

Katsanevakis, S., Zenetos, A., Belchior, C. \& Cardoso, A.C. (2013). Invading European Seas: Assessing pathways of introduction of marine aliens. Ocean \& Coastal Management, 76, 6474.

Koutsoubas, D., \& Voultsiadou-Koukoura, E. (1991). The occurrence of Rapana venosa (Valenciennes, 1846)(Gastropoda, Thaididae) in the Aegean Sea. Bollettino Malacologico, 26(10-12), 201-204. 
Lapointe, N. W., Thorson, J. T., \& Angermeier, P. L. (2012). Relative roles of natural and anthropogenic drivers of watershed invasibility in riverine ecosystems. Biological Invasions, 14(9), 1931-1945.

Lockwood, J. L., Hoopes, M. F., \& Marchetti, M. P. (2013). Invasion Ecology, $2^{\text {nd }}$ (ed). Chichester: Wiley-Blackwell.

Mackie, A. S., \& Hartley, J. P. (1990). Prionospio saccifera sp. nov.(Polychaeta: Spionidae) from Hong Kong and the Red Sea, with a redescription of Prionospio ehlersi Fauvel, 1928. The Marine Flora and Fauna of Hong Kong and Southern China, 1, 363-375.

MacNeil, C., Boets, P., Lock, K., \& Goethals, P. L. (2013). Potential effects of the invasive 'killer shrimp' (Dikerogammarus villosus) on macroinvertebrate assemblages and biomonitoring indices. Freshwater Biology, 58(1), 171-182.

Nunes A.L., Katsanevakis S., Zenetos A. \& Cardoso A.C. (2014). Gateways to alien invasions in the European Seas. Aquatic Invasions, 9, 133-144.

O'Dowd, D. J., Green, P. T., \& Lake, P. S. (2003). Invasional 'meltdown'on an oceanic island. Ecology Letters, 6(9), 812-817.

Olenin, S., Alemany, F., Cardoso, A.C., Gollasch, S., Goulletquer, P., Lehtiniemi, M., ...Ojaveer, H. (2010). Marine strategy framework directive. Task Group 2 report. Non-indigenous species. Luxembourg: office for official publications of the european communities, $44 \mathrm{pp}$.

Pace, M. L., Cole, J. J., Carpenter, S. R., \& Kitchell, J. F. (1999). Trophic cascades revealed in diverse ecosystems. Trends in Ecology \& Evolution, 14(12), 483-488.

Pearson, T. H., \& Rosenberg, R. (1978). Macrobenthic succession in relation to organic enrichment and pollution of the marine environment. Oceanography and Marine Biology Annual Review, 16, 229-311

Pyšek, P., \& Richardson, D. M. (2010). Invasive species, environmental change and management, and health. Annual Review of Environment and Resources, 35, 25-55.

Radashevsky, V. I., \& Hsieh, H. L. (2000). Polydora (Polychaeta: Spionidae) species from Taiwan. Zoological Studies-Taipei-, 39(3), 203-217.

Radashevsky, V. I., \& Selifonova, Z. P. (2013). Records of Polydora cornuta and Streblospio gynobranchiata (Annelida, Spionidae) from the Black Sea. Mediterranean Marine Science, 14(2), 261-269. 
Rosenberg, D. M., \& Resh, V. H. (Eds.). (1993). Freshwater biomonitoring and benthic macroinvertebrates. New York: Chapman \& Hall.

Saglam, H., \& Duzgunes, E. (2007). Deposition of egg capsule and larval development of Rapana venosa (Gastropoda: Muricidae) from the south-eastern Black Sea. Journal of the Marine Biological Association of the United Kingdom, 87(4), 953-957.

Shea, K., \& Chesson, P. (2002). Community ecology theory as a framework for biological invasions. Trends in Ecology \& Evolution, 17(4), 170-176.

Simberloff, D. (2014). Biological invasions: impacts, management, and controversies. Controversies in Science and Technology: From Sustainability to Surveillance, 4.

Simberloff, D., Martin, J.L., Genovesi, P., Maris, V., Wardle, D.A., Aronson, J., .. Pyšek, P. (2013). Impacts of biological invasions: what's what and the way forward. Trends in Ecology \& Evolution, 28(1), 58-66.

Simboura, N., Sigala, K., Voutsinas, E., \& Kalkan, E. (2008). First occurrence of the invasive alien species Polydora cornuta Bosc, 1802 (Polychaeta: Spionidae) on the coast of Greece (Elefsis Bay; Aegean Sea). Mediterranean Marine Science, 9(2), 119-124.

Streftaris, N., \& Zenetos, A. (2006). Alien marine species in the Mediterranean-the 100 'Worst Invasives' and their impact. Mediterranean Marine Science, 7(1), 87-118.

Strong, D.R. (1992). Are trophic cascades all wet? differentiation and donor-control in speciose ecosystems. Ecology, 73(3), 747-754.

Tena, J., Capaccioni-Azzati, R., Porras, R., \& Torres-Gavilá, F. J. (1991). Cuatro especies de poliquetos nuevas para las costas mediterráneas españolas en los sedimentos del antepuerto de Valencia. Miscel lània Zoològica, 15, 29-41.

Water Framework Directive, United Kingdom Advisory Group. (2014). Invertebrates (General Degradation) Whalley, Hawkes, Paisley \& Trigg (WHPT) metric in River Invertebrate Classification Tool (RICT), UKTAG River Assessment Method, Benthic invertebrate Fauna report. UKTAG.

WoRMS image (n.d(a)). Retrieved from the World Register of Marine Species website: http://www.marinespecies.org/aphia.php?p=image\&pic $=65202$

WoRMS image (n.d(b)). Retrieved from the World Register of Marine Species website: http://www.marinespecies.org/aphia.php?p=image\&pic $=68595$ 
Zenetos A., Gofas S., Morri C., Rosso A., Violanti D., Raso J.G., ...Azzurro E. (2012). Alien species in the Mediterranean Sea by 2012. A contribution to the application of European Union's Marine Strategy Framework Directive (MSFD). Part 2. Introduction trends and pathways. Mediterranean Marine Science 13, 328-352.

Zenetos, A., Ovalis, P., \& Kalogirou, S. (2009). Closing the gap: Cerithium scabridum Philippi, 1848 found in the South Aegean (Greece, Mediterranean Sea). Journal of Biological ResearchThessaloniki, 11, 107-110. 


\section{Extended Turkish Abstract \\ (Genişletilmiş Türkçe Özet)}

\section{4 - 2015 Yılları Arasında Türkiye Kıyılarında İzlenen İstilacı Makroomurgasız Türler}

İstilacı türler, denizel biyolojik çeşitliliğine yönelik en büyük küresel tehditlerden biri olarak görülmektedir. Denizel su kütlelerinde biyolojik istila oranı son yüzyılda artış göstermiş, ekolojik ve mali kayıpları yüzünden büyük endişe yaratmıştır. İstilacı türlerin, yerli topluluklar üzerinde de stres oluşturduğu ve/veya ekosistemlere farklı özellikler kazandırdığı tahmin edilmektedir. Ayrıca popülasyonların yapısında ve kompozisyonundaki değişiklikler ile ekosistem fonksiyonundaki bozulmalar (azot döngüsü, ışık geçirgenliği vb.) gibi çeşitli modifikasyonlardan sorumlu oldukları birçok araştırmacı tarafından dile getirilmektedir.

Doğal ve antropojenik kaynaklı küresel iklim değişiklikleri, istilaların coğrafi ve biyolojik sonuçlarını etkilemektedir. İstilacı türler su ürünleri yetiştiriciliği, kanal yapımı, kıyılardaki rekreasyonel faaliyetler, deniz taşımacılığı (balast sularının boşaltılması), turizm ve kültür balıkçılığı gibi son yıllarda artan insan faaliyetleri sonucu sucul ekosistemlere girmektedir. Tüm su kütlelerinde temel bir yöntem olan biyolojik izleme çalışmaları ile ekolojik değerlendirme ve antropojenik müdahalelerin etkileri ortaya konulmakla birlikte, istilacı tür varlığı da tespit edilmektedir.

Tatlı su ve kıyı-geçiş sularının ekolojik durumu, bentik makro omurgasızlar, fitoplanktonlar, makroalgler, balıklar gibi birçok biyolojik kalite unsuru kullanılarak belirlenmektedir. Bu biyolojik topluluklar arasında bentik makroomurgasızlar en yaygın kullanılan biyoindikatörler olup $\mathrm{AB} \mathrm{Su}$ Çerçeve Direktifi'nin uygulanmasında kullanılan biyolojik kalite unsurlarından biridir. Sucul ortamdaki bentik makroomurgasız türlerinin bulunma durumu, yeni türlerin girişi gibi göstergeler ortamın trofik düzeyi ile ilişkilidir. Bu nedenle biyolojik izleme metotlarının gelişimi indikatör niteliğindeki bentik omurgasız takson ve toplulukların varlığı ile güçlendirilmiştir. İstilacı türler kıyı ve geçiş sularında ekolojik değerlendirmede kullanılan bir gösterge olmasına rağmen, tatlı sularda kullanımı konusunda henüz bir fikir birliğine varılamamıştır.

Türkiye'nin Karadeniz, Marmara, Ege ve Akdeniz sahillerinde farklı hidrodinamik sistemlerin varlığının yanı sıra deniz taşıma-nakliye faaliyetlerini içeren yoğun bir deniz trafiği yaşanmaktadır. Türkiye'deki ticari limanlar ve deniz trafiğinin yoğun olduğu Çanakkale ve İstanbul boğazları istilacı türlerin girişlerini sağlayan önemli noktalar olarak bilinmektedir. Ayrıca, Süveyş Kanalı'nın açılmasıyla birlikte Akdeniz'in doğu kıyılarından yoğun şekilde istilacı tür girişi olmaktadır (Lesepsiyen göç). İstilacı türlerin ekosistemler üzerindeki etkileri ve sucul çevredeki rolleri Türkiye'de çalışılan konulardan birisi olup, bu konuda bilimsel yayımlar son yıllarda artmaktadır.

$\mathrm{Bu}$ çalışmada tespit edilen istilacı bentik makroomurgasız türleri Batı Akdeniz (2 istasyon), Doğu Akdeniz (1 istasyon) ve Doğu Karadeniz (2 istasyon) kıyılarında bulunan 5 istasyonda izlenmiş ve kayıt edilmiştir. İzleme çalışması yapılan bölgelerin biyoçeşitlilik ve bentik topluluk yapıları, istasyonlarda niteliksel ve niceliksel örnekleme yapılarak değerlendirilmiştir. Tüm izleme istasyonlarında yumuşak substratumdan makrofauna örneği Van Veen Grab $\left(0,1 \mathrm{~m}^{2}\right.$ örnekleme alanı) örnekleme ekipmanı ile üç tekrarlı (replikat) olarak gerçekleştirilmiştir. Yumuşak susbstratum örnekleri, 0,5 mm gözlü bir yıkama kovası boyunca filtrelenmiş ve $\% 4$ formaldehit solüsyonu içeren ayrı kutulara yerleştirilmiştir. Laboratuvarda, numuneler tatlı suda durulanmış, bir stereomikroskop altında tür seviyesinde tespit edilmiş ve \% 70 etanol içinde korunmuştur. 
Proje kapsamında Türkiye kıyılarında, Batı Akdeniz, Doğu Akdeniz ve Doğu Karadeniz kıyılarında bulunan toplam 5 istasyonda 4 istilacı tür tespit edilmiştir.

Polydora cornuta Bosc, 1802 (Spionidae: Polychaeta); Batı Akdeniz havzası EDSBAKKS01 istasyonunda yaz döneminde örneklenmiştir. Akdeniz'de en tehlikeli istilacı türlerden biri olarak kabul edilmektedir. İspanya, Yunanistan, Atlantik-Pasifik arası ve Marmara denizi gibi çeşitli bölgelerde daha önce görüldüğüne dair kayıtlar bulunmaktadır. Literatürde nasıl yayıldığına dair kesin bir kanı olmamasına rağmen, gemicilik ve kültür balıkçılığı faaliyetlerinin $P$. cornuta türünün Akdeniz'de görülmesine sebep olduğu düşünülmektedir.

Prionospio saccifera Mackie \& Hartley, 1990 (Spionidae: Polychaeta); Batı Akdeniz havzası EDSBAKKS09 istasyonunda ilkbahar döneminde örneklenmiştir. İlk olarak 1990 yılında Hong Kong'ta kaydı tutulmuş olan P. saccifera, batı Pasifik ve Hint Okyanusunda yaygın olarak görülmekte olup, Akdeniz'e girişinin Süveyş Kanalı vasıtasıyla olduğu düşünülmektedir. Akdeniz için ise ilk kayıt 1999 yılında Çınar ve Ergen tarafından tutulmuştur. Akdeniz'de görülmesi, dünya çapında dağılımının genişlediğinin bir göstergesidir.

Cerithium scabridum Philippi, 1848 (Cerithiidae: Gastropoda); Ceyhan havzas1 EDSCEGS02 istasyonunda ilkbahar döneminde örneklenmiştir. P. saccifera gibi yayılımında Lesepsiyen göç adı verilen ve Süveyş Kanalı aracılığıyla meydana gelen hareketliliğin rolü olduğu düşünülmektedir. Doğu Akdeniz'den batıya doğru yayılmasında gemicilik faaliyetlerinin de etken olduğu düşünülmektedir.

Rapana venosa (Valenciennes, 1846) (Muricidae: Gastropoda) ;Doğu Karadeniz havzas1 EDSDKKS02 istasyonunda ilkbahar ve EDSDKKS03 istasyonunda yaz döneminde örneklenmiştir. Asya kökenli büyük bir avcı tür olan R. venosa, Karadeniz'de ilk defa 1947'de kaydedilmiş olup buradan Ege ve Adriatik Denizi'ne yayılmıştır. Büyük avcı türlerin eksikliğinden dolayı Karadeniz'de hızlıca çoğalabilmektedir. Karadeniz'de ve Akdeniz'in doğusunda bulunan $R$. venosa türlerinin dünyanın çeşitli yerlerine gemilerin balast suları ile yayıldığı düşünülmektedir.

$\mathrm{Bu}$ çalışma, Orman ve Su İşleri Bakanlığı Su Yönetimi Genel Müdürlüğü tarafından finanse edilen biyolojik izleme projesi (Proje No: 2011K050400, Türkiye'ye Özgü Su Kalitesi Ekolojik Değerlendirme Sisteminin Kurulması Projesi) kapsamında Türkiye kıyılarından örneklenen istilacı türler hakkında yapılmış bir incelemedir. 2014 ve 2015 yılları arasında gerçekleştirilen izleme projesi boyunca, Türkiye kıyılarından 4 istilacı ve 7 yabancı tür tespit edilmiştir. Teşhisi yapılan istilacı türler; Polydora cornuta Bosc 1802; Prionospio saccifera Mackie \& Hartley 1990; Cerithium scabridum Philippi 1848 ve Rapana venosa (Valenciennes, 1846). Bu türlerin bazı coğrafik dağılım verileri kısaca incelenmiştir. 